\title{
SERVICE BY MAIL-IS THE STAMP OF APPROVAL FROM THE HAGUE CONVENTION ALWAYS ENOUGH?
}

\author{
THE HoNORABLE JOSEPH F. WeIS, JR.*
}

\section{INTRODUCTION}

When the Federal Rules of Civil Procedure were amended in 1963, the drafters hoped that their example would encourage foreign states to be receptive to a new convention that would ease restrictions on service of process in transnational litigation. Philip Amram, one of the United States's leading lawyers in the international law field, announced that the rules and legislative changes did not depend on reciprocity. ${ }^{1}$ But certainly there was an underlying anticipation that the United States's example would be followed by other nations agreeing to allow more flexibility in service of process. To some extent, that goal was achieved.

The Hague Convention on the Service Abroad of Judicial and Extrajudicial Documents in Civil and Commercial Matters ${ }^{2}$ succeeded in providing a framework that substantially improved the means of serving process in transnational litigation. "The Europeans obtained a more formal method for serving process in the United States and the Americans gained assurances that service on U.S. defendants would be reasonably calculated to give them actual notice." 3 Although the Hague Convention relaxed the rules for international service of process, many restrictions still apply and the means provided for service are not as simple as those applicable in U.S. domestic cases.

Generally, it seems that U.S. lawyers, particularly those active in the products liability field, are less than enthusiastic about the Hague Convention. Those familiar with the treaty chafe at what they consider time-consuming and unnecessarily complex steps required to accomplish what is routine in domestic litigation. In the absence of energetic judicial direction, the bar has attempted to avoid the Convention's procedures and, instead, use the more familiar domestic methods.

It may be concluded that this evasion is caused by a lack of familiarity with the Convention's requirements. The Advisory Committee on the Federal Rules

Copyright $(\mathcal{C} 1994$ by Law and Contemporary Problems

* U.S. Circuit Judge, U.S. Court of Appeals for the Third Circuit, Pittsburgh, Pennsylvania.

1. S. REP. No. 6, 90th Cong., 1st Sess. 9-11 (1967) [hereinafter SENATE REPORT].

2. Opened for signature Nov. 15, 1965, art. 2, 20 U.S.T. 361, 658 U.N.T.S. 163 [hereinafter Convention].

3. Gary B. Born \& David Westin, International Civil litigation in United States COURTS 138 (1989). 
of Civil Procedure has attempted to remedy this problem by calling the attention of the bar to the Convention. However, in a recent proposal for amendments to the Rules, the Committee itself drafted an informal waiver procedure that would have bypassed the Convention in a significant number of cases. $^{4}$

The proposed Rule 4(d) would have permitted a plaintiff to send a copy of a complaint that had been filed in a federal court, accompanied by a request that the defendant execute an enclosed waiver of formal service. ${ }^{5}$ The complaint and waiver form were to be sent by first class mail. Failure to accede to a waiver could have subjected that party to the costs of effecting service in the usual fashion. This suggested rule would have had the advantage of eliminating nonproductive expense and endorsing the practice of using the mails to serve process and give notice of a lawsuit.

The proposal of this new rule, however, aroused opposition by some signatories as well as nonparties to the Hague Convention. ${ }^{6}$ The adverse comments were generally directed at the provision that permitted the imposition of costs in securing service if the request for waiver were not accepted. To meet these concerns, the Standing Committee and the Judicial Conference changed the proposal by making the cost assessment applicable only if both the plaintiff and defendant were "located within the United States." The new Rule was adopted in this form. As a result, a refusal to waive service of process will have no adverse consequences for a foreign defendant. ${ }^{7}$ Despite this compromise, it remains to be seen whether some nations will permit their citizens to exercise the waiver. The real test will be whether a judgment obtained in a suit initiated by a waiver will be enforced by the courts of a foreign defendant's home country.

As the controversy over the proposed amendment to the Federal Rules demonstrates, the Convention, albeit a substantial step forward, did not solve all of the problems in transnational service of process. Much of the difficulty has centered on the U.S. preference for service by mail, a method that has the merits of simplicity and minimal expense.

4. FED. R. CIV. P. 4(d) (Federal Rules of Civil Procedure including all proposed amendments adopted by Congress effective December 1, 1993); see also Amendments to Federal Rules of Civil Procedure and Forms, 146 F.R.D. 401, 540-43 (1992) (standing committee proposed Rule 4(d)).

5. Committee on Rules of Practice and Procedure, Report of The Judicial CONFERENCE, Agenda E-19, Rules n.2 (Sept. 1992).

6. See Diplomatic Note from the British Embassy to the United States Department of State (Feb. 20, 1991) (unpublished record of the Standing Committee on Rules of Practice and Procedure of the Judicial Conference of the United States) (on file with author); Diplomatic Note from the Irish Embassy to the United States Department of State (unpublished record of the Standing Committee on Rules of Practice and Procedure of the Judicial Conference of the United States) (on file with author); see also Amendments to Federal Rules of Civil Procedure and Forms, supra note 4, at 521 (commenting on development of proposed Rule 4(d)); U.S. DEP'T OF JUSTICE, COMMENTS ON PROPOSED AMENDMENTS to the Federal Rules of Civil Procedure: Proposed Revisions to Rule 4(D) (Service of Process on individuals in Foreign states) AND TO RULE 26(A)(5) (Extraterritorial discovery) 1-4 (1992).

7. See FED. R. CIV. P. 4(d); see also Amendments to Federal Rules of Civil Procedure and Forms, supra note 4, at 414-16 (standing committee notes on Rule 4(d)). 
Part of the problem is the mystique that for so many years has been a feature of service of process in both transnational and domestic litigation. A hard-headed reality in this area has yet to be fully recognized. Whether service of process actually confers jurisdiction in the sense that it authorizes the court to adjudicate a dispute is a murky concept in U.S. law. ${ }^{8}$ Nevertheless, it is clear that an important function of service of process is to give notice. ${ }^{9}$ That task can be performed efficiently and inexpensively through the use of postal channels; thus, efforts to simplify service of process through the mails deserve encouragement. That has been a goal of the Advisory Committee on Civil Rules and the Standing Committee over the years, but their rulemaking authority, of course, does not directly extend to foreign nations.

\section{II}

\section{INTERPRETATION OF THE REQUIREMENTS OF SERVICE UNDER THE CONVENTION BY U.S. COURTS}

The Convention has clarified some aspects of service by mail, but has left others in a state of uncertainty. The treaty provides for service through the use of Central Authorities ${ }^{10}$ in each signatory country, but also deliberately does not discourage the use of other, less formal methods. Article 10 of the Convention reads:

Provided the state of destination does not object, the present Convention shall not interfere with-

(a) the freedom to send judicial documents, by postal channels, directly to persons abroad,

(b) the freedom of judicial officers, officials or other competent persons of the State of origin to effect service of judicial documents directly through the judicial officers, officials or other competent persons of the State of destination,

(c) the freedom of any person interested in a judicial proceeding to effect service of judicial documents directly through the judicial officers, officials or other competent persons of the State of destination."

In Article 21, the Convention further provides that each contracting state is to make known its "opposition to the use of methods of transmission pursuant to Articles 8 and 10." In the absence of a formally expressed opposition, it is generally assumed that a signatory nation accepts the methods listed in Article $10 . .^{12}$

8. See generally Burnham v. Superior Court of Cal., 495 U.S. 604, 610-16 (1990) (discussing whether service of process confers jurisdiction).

9. See, e.g., DeJames v. Magnificence Carriers, Inc., 654 F.2d 280, 288 (3d Cir. 1981).

10. A "Central Authority" is designated by a state "to receive requests for service coming from other contracting States ...." Convention, supra note 2, art. 2.

11. Id. art. 10 .

12. See Adair Dyer, Hague Conference on Private int'l law, Preliminary Doc. No. 1 , CHECKLIST FOR THE DISCUSSIONS OF THE SPECIAL COMM'N OF APRIL 1989 ON THE OPERATION OF THE Hague Conventions on the Service of Process abroad and on the Taking of EVIDENCE ABROAD $12 \mathrm{cmt} .18$ (March 1989); see also 1 BRUNO A. RISTAU, INTERNATIONAL JUDICIAL ASSISTANCE: CIVIL \& COMMERCIAL §§ 4-1-5, 4-3-5, at 120-21, 148-49 (1990). 
The surface simplicity of the Convention in this aspect, however, has not prevented uncertainty in the United States over the meaning of Article 10(a). Judicial interpretation has focused on the fact that other articles of the Convention refer to the "service" of judicial documents, but Article 10(a) uses the language "freedom to send judicial documents."13 Some U.S. courts addressing the use of the different language in the various articles have held that the wording in Article 10(a) indicates that it is not intended to apply to service of process. ${ }^{14}$ Others have taken the position that the use of the word "send" is not designed to make 10(a) different from 10(b) and 10(c) and that Article 10 as a whole applies to service of process. ${ }^{15}$ Courts taking the latter position, consequently, hold that when the nation in which the recipient resides has not filed a formal objection to $10(a)$, service by mail is proper. ${ }^{16}$

Most of the opinions in this country discussing Article 10(a) do so in the context of resolving disputes over service on Japanese parties. Japan has filed a formal opposition to Article 10(b) and (c) (use of consular and diplomatic channels), but not to Article 10(a) (mail service). ${ }^{17}$

The courts holding that service by registered mail upon a corporation in Japan does not comply with the Hague Convention have relied upon two bases for that determination. Some opinions cite the familiar canon of construction that where the legislative body includes particular wording in one section of a statute but omits that language in other parts of the same act, it is presumed that the disparate inclusion or exclusion was intentional and with purpose. ${ }^{18}$ Thus, the failure of Article 10(a) to use the words "service of process" indicates that service by mail was not an approved method. ${ }^{19}$

Those courts also note that service of process by registered mail is not permitted for domestic suits in Japan. ${ }^{20}$ Article 161 of the Japanese Code of Civil Procedure does not permit a plaintiff to serve process by mailing a complaint directly to the defendant. ${ }^{21}$ Service of process through the mail is permissible only when " $[t]$ he court clerk stamps the outside of the envelope [containing the required documents] with a notice of special service [and] ... [ $t$ ] he mail-carrier acts as a special officer of the court by recording the proof of delivery" and returning it to the court. ${ }^{22}$

13. See, e.g., Bankston v. Toyota Motor Corp., 889 F.2d 172, 173-74 (8th Cir. 1989); Ackermann v. Levine, 788 F.2d 830, 839 (2d Cir. 1986).

14. See, e.g., Bankston, 889 F.2d at 173-74.

15. See, e.g., Ackermann, 788 F.2d at 839.

16. Id.

17. See 1 RistAU, supra note 12 , at A-47.

18. See, e.g., Bankston, 889 F.2d at 173-74.

19. Id.

20. See, e.g., Bankston v. Toyota Motor Corp., 123 F.R.D. 595,599 (W.D. Ark. 1989); Suzuki Motor Co. v. Superior Court, 249 Cal. Rptr. 376, 379 (Cal. Ct. App. 1988).

21. Bankston, 123 F.R.D. at 598 (citing Masayuki Sakai \& Lynn F. Pickard, Service of Process on a Japanese Defendant to Commence a Foreign Lawsuit, YUASA \& HARA PATENT NEWS, Summer 1978, at 5-13 (English ed.)).

22. Robert W. Peterson, Jurisdiction and the Japanese Defendant, 25 SANTA CLARA L. REV. 555, 577 (1985). 
Because of these restrictions on service of process by registered mail in Japanese domestic suits, many courts and commentators have reasoned that it is highly unlikely that Japan's failure to object to Article 10(a) was intended to authorize mail service in that country for suits filed in the United States. ${ }^{23}$ For example, in Gallagher v. Mazda Motor of America, the district judge found "it implausible that Japan, which objected to the 'less intrusive' paragraphs (b) and (c), and which does not permit service of process by registered mail in domestic cases, would consent to the service of foreign process by mail."24

The reasoning used by the courts that have quashed service of process by mail in Japan is weighty and not to be lightly disregarded, but a number of equally thoughtful opinions have taken the view that such service is valid. In those opinions, the courts construe the language of Article 10(a), specifically the word "send," as permitting service of process by mail. ${ }^{25}$ In his commentary to the Hague Convention, Bruno Ristau asserts that Article 10(a)'s use of the word "send" in connection with judicial documents (in French, "d'adresser ... des actes judiciaries") includes "service of process." 26 Conceding that the contrary position raises questions that "are not insubstantial," he nevertheless concludes that " $[\mathrm{t}]$ he use of different terms in the several paragraphs of Article 10 may well be attributed to careless drafting."27

In preparing Article 10, it appears that the rapporteur tracked Article 6 of the 1954 Convention (to which the United States is not a party). That treaty provided:

The provisions of the preceding articles do not preclude:

23. Suzuki, 249 Cal. Rptr. at 379; see Gallagher v. Mazda Motor of Am., Inc., 781 F. Supp. 1079 (E.D. Pa. 1992); Hantover, Inc. v. Omet, S.N.C. of Volentieri \& C., 688 F. Supp. 1377, 1385 (W.D. Mo. 1988); Prost v. Honda Motor Co., 122 F.R.D. 215, 216 (E.D. Mo. 1987); Pochop v. Toyota Motor Co., 111 F.R.D. 464, 466 (S.D. Miss. 1986); Mommsen v. Toro Co., 108 F.R.D. 444, 446 (S.D. Iowa 1985). See generally Fleming v. Yamaha Motor Co., 774 F. Supp. 992, 995 (W.D. Va. 1991); Raffa v. Nissan Motor Co., 141 F.R.D. 45 (E.D. Pa. 1991); Wasden v. Yamaha Motor Corp., 131 F.R.D. 206 (M.D. Fla. 1990); McClenon v. Nissan Motor Corp., 726 F. Supp. 822 (N.D. Fla. 1989); Sheets v. Yamaha Motors Corp., 657 F. Supp. 319 (E.D. La. 1987); Cooper v. Makita U.S.A., Inc., 117 F.R.D. 16 (D. Me. 1987); Reynolds v. Koh, 490 N.Y.S.2d 295 (N.Y. App. Div. 1985); Ordmandy v. Lynn, 472 N.Y.S.2d 274 (Sup. Ct. 1984); E. Charles Routh, Litigation Between Japanese and American Parties, in CURRENT LEGAL ASPECTS OF DOING BUSINESS IN JAPAN AND EAST ASIA 190-91 (John Owen Haley ed., 1978).

24. Gallagher v. Mazda Motor of Am., Inc., 781 F. Supp. 1079, 1082 (E.D. Pa. 1992) (citations omitted).

25. See, e.g., Ackermann v. Levine, 788 F.2d 830, 839 (2d Cir. 1986). In that case, the court of appeals reviewed the validity of service by a German litigant on an American defendant. The court in Berlin had forwarded a summons and complaint to the German consulate in New York, which then sent the documents by registered mail to the defendant at his residence in New York. The court of appeals observed that the United States had not filed an opposition to Article 10(a), and so, consequently, this country did not oppose service by mail. For additional source material, see Hammond v. Honda Motor Co., 128 F.R.D. 638 (D.S.C. 1989); Smith v. Dainichi Kinzoku Kogyo Co., 680 F. Supp. 847 (W.D. Tex. 1988); Turick v. Yamaha Motor Corp., 121 F.R.D. 32, 34-35 (S.D.N.Y. 1988); Newport Components v. NEC Home Elec., 671 F. Supp. 1525, $1541-42$ (C.D. Cal. 1987); Lemme v. Wine of Japan Import, Inc., 631 F. Supp. 456, 464 (E.D.N.Y. 1986); Zisman v. Sieger, 106 F.R.D. 194, 199-200 (N.D. Ill. 1985); Weight v. Kawasaki Heavy Indus., 597 F. Supp. 1082, 1085-86 (E.D. Va. 1984); Chrysler Corp. v. General Motors, 589 F. Supp. 1182, 1206 (D.D.C. 1984).

26. 1 RISTAU, supra note $12, \S 4-3-5$, at $148-49$.

27. Id. at 149 . 
1. The faculty to forward process directly by mail to interested parties abroad;

2. The faculty of the interested parties to have service made directly through competent serving officers (officers ministeriels) or officials of the country of destination;

3. The faculty for each state to have service directed to persons abroad made through its diplomatic or consular agents. ${ }^{28}$

The parallels between that article and Article 10 of the 1964 Hague Convention are apparent and lend strength to Ristau's conclusion that the variations in language between subsections (a), (b), and (c) were not intended to be of significance.

The context of Article 10(a) also suggests that "send" includes service of process. The scope of the Hague Convention encompasses "service abroad of judicial documents." It follows that the language in Article 10(a) providing for the "freedom to send judicial documents by postal channels" would be superfluous unless it applied to service of process. ${ }^{29}$ Moreover, "the reference appears in the context of other alternatives to the use of the 'Central Authority' created by the treaty." 30

The interpretations of Article 10(a) by those participating in its drafting also support the conclusion that "send" includes service of process. Philip Amram, a member of the U.S. delegation to the Conference, said of the scope of the Convention: "Optional techniques may be used, for example-(1) diplomatic and consular channels (arts. 8 and 9)[, and] (2) unless the requested State objects, direct service by mail or transmission to a process server for service (art. 10)."31 Moreover, a handbook prepared by the Permanent Bureau of the Hague Conference on Private International Law in "close cooperation" with the parties to the Convention states: "The majority of States do not oppose the forwarding of judicial documents originating in other Contracting States directly by mail to persons on their territory."32

Finally, some courts have also concluded that service by mail is justified based on policy reasons. These courts note that service of process by means of registered mail is less intrusive than alternative means that might require official government action within the boundaries of the local state. Moreover, service by mail minimizes any imposition on local authorities. ${ }^{33}$

28. Hague Convention Relating to Civil Procedure, Mar. 1, 1954, 286 U.N.T.S. 265.

29. See, e.g., Shoei Kako Co. v. Superior Court, 109 Cal. Rptr. 402, 411 (Cal. Ct. App. 1973).

30. Id.

31. SENATE REPORT, supra note 1 , at 13.

32. Hague Conference on Private int'l Law, Practical handbook on the Operation OF THE HAgue CONVENTION OF 15 NOVEMBER 1965 ON THE SERVICE ABROAD OF JUdICIAL AND EXTRAJUDICIAL DOCUMENTS IN CIVIL AND COMMERCIAL MATTERS 42 (2d ed. 1992). The handbook further states that the Bankston line of cases "appear[s] to go against the understanding of the French version of Article 10a of the 1965 Convention as it had existed throughout the entire history of the predecessor conventions from 1894 through 1954." Id. at 45. See generally Committee on Fed. Courts of the N.Y. State Bar Ass'n, Service of Process Abroad: A Nuts and Bolts Guide, 122 F.R.D. 63 (1989).

33. See, e.g., Chrysler Corp. v. General Motors, 589 F. Supp. 1182, 1206 (D.D.C. 1984) (quoting F.T.C. v. Compagnie De Saint-Gobain-Pont-A-Mousson, 636 F.2d 1300, 1313 \& n.68 (D.C. Cir. 1980). 
Mr. Amram's comments and the Permanent Bureau's handbook are not cited in the many opinions holding that Article 10(a) does not authorize service of process, leaving open to question the adequacy of briefing in those cases. In the instances where service on Japanese corporations was at issue, the conflicting views on whether Japanese law authorized service by mail in its domestic litigation often do not make clear that service by mail is permitted, but only under the authority and direction ' of the Japanese courts.

When the Special Commission of April 1989 on the Operation of the Hague Convention on the Service Abroad of Judicial and Extrajudicial Documents convened, one of the questions asked of participants was whether there had been "court decisions in your country interpreting Article 10a," noting that some U.S. courts had held that mail service was ineffective. In response, the Japanese delegates issued the following statement on the part of their government:

Japan has not declared that it objects to the sending of judicial documents, by postal channels, directly to persons abroad. In this connection, Japan has made it clear that no objection to the use of postal channels for sending judicial documents to persons in Japan does not necessarily imply that the sending by such a method is considered valid service in Japan; it merely indicates that Japan does not consider it as infringement of its sovereign power. ${ }^{34}$

The "clarification" in the Japanese statement should not give comfort to U.S. litigants who choose to forgo the Convention procedures in favor of the less complex and inexpensive method of service by direct mail to Japan. The ease of effecting service by mail will likely be outweighed by the difficulty in enforcing such a judgment in Japan or anywhere else outside the United States.

Japan, like civil law countries, considers service of process to be an official government act. As Professor Kojima stated during the symposium: "Service is an official, public act in Japan," ${ }^{35}$ and legal certainty is an important aspect. Although it apparently does not consider mail service an infringement of its sovereign power, Japan may nevertheless take the position that service upon a person in that country by U.S. courts or litigants constitutes an exercise of jurisdiction by the United States within the territory of Japan that is not effective. It is therefore questionable whether Japan will recognize the validity of a judgment in a suit where service was completed by mail. ${ }^{36}$

34. Hague Conference on Private INT'L Law, Report on the Work of the SPECIAL COMM'N OF APRIL 1989 ON THE OPERATION OF THE HAGUE CONVENTIONS OF 15 NOVEMBER 1965 ON THE SERVICE ABROAD OF JUdICIAL AND EXTRAJUdICIAL DOCUMENTS IN CIVIL OR COMMERCIAL MATTERS AND OF 18 MARCH 1970 ON THE TAKING OF EVIDENCE ABROAD IN CIVIL OR COMMERCIAL MATTERS 11 (August 1989). A team of commentators has said that, in Japan, failing personal service by delivery, substitute service, or leaving documents, the court clerk may send a copy by registered mail (effective whether addressee receives it or not). Chin Kim \& Eliseo Z. Sisneros, Comparative Overview of Service of Process: United States, Japan, and Attempts at International Unity, 23 VAND. J. TRANSNAT'L L. 299, 307 n.62 (1990) (citing T. Hattori \& D. Henderson, Civil Procedure IN JAPAN $\S 7.01[4][\mathrm{d}](1985))$.

35. Takeshi Kojima, Remarks at the Law and Contemporary Problems Symposium on Jan. 4, 1993.

36. See U.S. DEP'T OF STATE, SERviCE OF PROCESS IN JAPAN 3 (June 1987). 
The inconsistency of U.S. decisions applying Article 10(a) to Japanese defendants is in large measure due to the failure of the Japanese government either to formally object to Article 10(a) or to accept it without qualification. Apparently, the Japanese delegates did not realize that Article 10(a) could be in conflict with their domestic practice in serving process. It may be that, because Japan utilizes service by mail only under the direction of a court official, the delegates did not recognize the likelihood that it would be used directly by U.S. litigants as the method of choice.

Had Japan objected to Article 10(a), as it objected to Article 10(b) and (c), the uncertainty in case law likely would not have arisen because U.S. judges would have honored the objection. Courts in this country have consistently recognized Germany's unwillingness to permit service by mail as manifested by its formal opposition to Article 10(a). ${ }^{37}$

Yoshio Ohara, a Professor of Law at Kobe University, agrees that Japan "should have declared, or even now should declare, its objection to [Article 10(a)]." ${ }^{38}$ He concedes that it is not clear why Japan did not object and why it abstained from the German proposal, made in 1964, to modify Article 10(á) by requiring the destination state to expressly consent to service by mail. Professor Ohara points out that Japan does not permit its citizens to serve process by mail in foreign countries, unlike U.S. litigants who enjoy that privilege under Federal Rule of Civil Procedure 4(i)(1)(D). Because Japan has not yet amended its own Code of Civil Procedure to permit service by mail in foreign countries by its own citizens, reciprocity does not require that Japan extend to foreigners a privilege it denies to its own people. However, one would hope that instead of following Professor Ohara's suggestion, Japan would adopt the more enlightened view and recognize service by mail as legitimate.

As noted earlier, foreign nations' sensibilities over service of process have been recognized by the Civil Rules Advisory Committee. The new Federal Rule of Civil Procedure 4 provides:

[I]f there is no internationally agreed means of service or the applicable international agreement allows other means of service, provided that service is reasonably calculated to give notice[, service may be made] ... (C) unless prohibited by the law of the foreign country, by ... (ii) any form of mail requiring a signed receipt, to be addressed and dispatched by the clerk of the court to the party to be served . . . 39

The new rule will not, in itself, resolve the problems of service by mail in Japan because of the equivocal nature of the Japanese position. It thus leaves U.S. courts to continue their struggle with the issue.

37. See, e.g., Vorhees v. Fischer \& Krecke, 697 F.2d 574 (4th Cir. 1983).

38. Yoshio Ohara, Judicial Assistance to Be Afforded by Japan for Proceedings in the United States, 23 INT'L LAW. 10, 16 (1989).

39. FED. R. CIV. P. 4(f)(2); see Amendments to Federal Rules of Civil Procedure and Forms, supra note 4 , at 410 (standing committee proposed Rule 4(f)). 


\section{III}

\section{Impact of New Federal Rule of Civil Procedure 4}

The most frequent application of the new Rule 4 is. likely to be in cases where service of process occurs in a country that is not a signatory to the Hague Convention. This situation is illustrated by Umbenhauer $v$. Woog, ${ }^{40}$ where the court gave a plaintiff the option to use mail or letters rogatory to serve a Swiss resident.

Switzerland is not a signatory to the Convention and has forcefully objected to service of process by mail within its borders. In an effort to forestall continuing protests from the Swiss and other governments with similar views, some years ago the State Department sought the assistance of the Administrative Office of the United States Courts. Responding to the State Department request, the General Counsel of the Administrative Office sent a letter to the clerks of the district courts notifying them that they should not attempt service of process by mail in Switzerland and other designated countries.

In the Umbenhauer case, the clerk of the United States District Court for the Eastern District of Pennsylvania refused to send a summons and complaint by registered mail to the individual defendant living in Switzerland. The district court agreed with the clerk's action and dismissed the case. The court of appeals concluded, however, that the clerk (and thus the Administrative Office of the United States and the State Department as well) was bound by the terms of Federal Rule of Civil Procedure 4(i)(1)(D), ${ }^{41}$ allowing service by mail in foreign countries or, in the alternative, by subsection (e), authorizing service in accordance with state procedures. ${ }^{42}$

In its opinion approving an option for service by mail, the court of appeals did not cite the Advisory Committee note to the then-current Rule 4 that pointed out "[s]ervice of process beyond the territorial limits of the United States may involve difficulties not encountered in the case of domestic service." ${ }^{43}$ The Committee explained that some countries would consider such service of process offensive. The note further states that "one of the purposes of subdivision (i) is to allow accommodation to the policies and procedures of the foreign country." ${ }^{44}$ In addition, subparagraph (E) of paragraph 1 provides that service may be made "as directed by order of the court." The Committee note observes that subparagraph $(\mathrm{E})$ "adds flexibility by permitting the court by order to tailor the manner of service to fit the necessities of a particular case or

40. 969 F.2d 25 (3d Cir. 1992).

41. FED. R. CIV. P. 4(i)(1)(D) (1988) (repealed 1993).

42. Umbenhauer, 969 F.2d at 31-34.

43. FED. R. CIV. P. 4(i) (advisory committee note to 1963 amendment).

44. Id. (emphasis omitted). Born and Westin ask the question: "Where would a U.S. Court derive the power to forbid service authorized by Congress in Rule 4 on the grounds that the service violated foreign law?" BORN \& WESTIN, supra note 3, at 129. 
the peculiar requirements of the law of the country in which the service is to be made." 45

Despite its recognition of Swiss objections, the court of appeals apparently believed it had no discretion to require the plaintiff to choose a method of service that would not offend the Swiss government. The court, however, did recognize that failure to use letters rogatory would likely make the judgment unenforceable in Switzerland. The court's opinion acknowledged that the thenproposed amendment to Rule 4 , prohibiting service by a means violating the law of the recipient's country, would have required a different result. ${ }^{46}$

The Umbenhauer case demonstrates the need for comity, an admonition that was not included in the text of the version of Rule 4 in place at the time. The new Rule $4(f)(2)(C)$ gives specific recognition to that important consideration. $^{47}$ Thus, although the current Rule 4 may not completely answer the questions posed by the Japanese situation, it does seem to respect the unwillingness of Switzerland and other nations to approve the use of mail service.

\section{IV}

\section{AVOIDANCE OF CONVENTION REQUIREMENTS FOR EFFECTIVE SERVICE}

In Volkswagenwerk Aktiengesellschaft $v$. Schlunk, ${ }^{48}$ the Supreme Court approved a state law determination that a corporate subsidiary was an effective agent to receive service of process on behalf of its foreign parent. Hence, because no transmission of judicial documents to a foreign country was required to make service effective, the Convention was not implicated. Just how far the Schlunk principle will extend remains to be seen.

An interesting related issue is posed by Melia v. Les Grands Chais de France, ${ }^{49}$ where the defendant was a French corporation with its principal place of business in that country. Although France is a signatory to the Convention, the plaintiff sought to serve the defendant in several ways-none of them through the Central Authority or by other methods permitted by the Convention.

The plaintiff relied on a Rhode Island statute providing that a foreign corporation carrying on business within the state is presumed to consent to service upon the Secretary of State. The statute provides that after service is made upon the Secretary, "he or she shall immediately cause one of such copies to be forwarded by registered mail, addressed to the corporation at its principal office."50

45. FED. R. CIV. P. 4(i) (advisory committee note to 1963 amendment).

46. Umbenhauer, 969 F.2d at 32-33 (discussing FED. R. CIV. P. 4(f) (advisory committee note)); see also Amendments to Federal Rules of Civil Procedure and Forms, supra note 4, at 544 (standing committee proposed Rule 4(f)).

47. Id.

48. 486 U.S. 694 (1988).

49. 135 F.R.D. 28 (D.R.I. 1991).

50. R.I. GEN. LAWS § 7-1.1-108(b) (1992). 
The district court held that service was complete when the Secretary was served, and, because the statute did not require the plaintiff to mail a copy directly to the defendant in addition to that sent by the Secretary of State, the Hague Convention did not apply. ${ }^{51}$ The court paraphrased Schlunk's holding to be: "If the forum state requires transmission abroad to effect service, the Convention applies; if, however, service can be effected without the transmission abroad of documents, the Hague Convention does not apply . . .."52

Melia appears to be an overly expansive reading of Schlunk. Article 15 of the Convention provides that a judgment may not be entered unless a foreign defendant receives adequate and timely notice of the lawsuit. One of the stated objectives of the Convention is "to create appropriate means to ensure that judicial and extrajudicial documents to be served abroad shall be brought to the notice of the addressee in sufficient time." 53

In asserting that the act of service is complete when the Secretary of State receives the documents, Melia seems to have approved to some extent a form of service that troubled the Hague Conference-notification au parquet. That procedure permits deposit of documents with a local official who is generally expected to transmit them abroad. However, the time for filing an answer begins to run on the day the official receives the documents and, allegedly, no sanction exists for failure to transmit them. ${ }^{54}$

Philip Amram was concerned with the due process aspects of notification au parquet. He cautioned: "Frequently, both the time for moving to open judgment and to appeal will have long since expired before the defendant finds out about the judgment." 55 Mr. Amram noted that such inequitable results are avoided in U.S. law by due process restrictions on long-arm statutes that require "the form and content of the defendant's notice [to provide] knowledge of the proceedings and the opportunity to defend himself in due time." ${ }^{\text {" } 6} \mathrm{Mr}$. Amram pointed out that if in a particular state "service on the appropriate official need be accompanied only by a minimum effort to notify the defendant and if a default judgment may be entered in as short a period as thirty or sixty days, the convention will require greater protection of the defendant who lives outside the United States in a convention country." 57

Not all district courts have followed the same path as Melia. In McClenon v. Nissan Motor Corp. ${ }^{58}$ for example, the court held that because the plaintiff was required by the substituted service statute to send a copy of the summons

51. In the only Rhode Island case addressing the scope of section 7-1.1-108, the Supreme Court of Rhode Island held that the section did not authorize such service outside of the Hague Convention procedures. Cipolla v. Picard Porsche Audi, Inc., 496 A.2d 130, 131-32 (R.I. 1985). The Melia court found the scope of the Hague Convention was a matter of federal law and refused to follow Cipolla. 135 F.R.D. at 30-31.

52. Melia, 135 F.R.D. at 30.

53. Schlunk, 486 U.S. at 702-03.

54. See id. at 703-04.

55. SENATE REPORT, supra note 1 , at 12.

56. Id.

57. Id. at 15 .

58. 726 F. Supp. 822 (N.D. Fla. 1989). 
and complaint to both the Secretary of State and the defendant, the process involved transmission of documents abroad and the Convention was applicable. $^{59}$

Schlunk did allow avoidance of the Hague Convention, but at least its decision rested on a realistic and pragmatic concept of notice. Service on the subsidiary undoubtedly would get to the attention of the parent. After all, their activities were closely related. Melia, however, fails to consider the difference between a wholly-owned subsidiary of the defendant and a state official who has no actual relationship with the defendant and whose capacity to accept service is in fact a legal fiction. Melia, one may hope, will remain an aberration.

\section{$\mathrm{V}$}

\section{Translation ReQuirement for SeRvice Under the Convention}

Translation of judicial documents into the language of the destination country is another vexing problem that arises in the context of international service of process. Professor Ohara points out that failure to furnish translated copies of judicial documents imposes a hardship on Japanese citizens. ${ }^{60}$ One U.S. court cavalierly dismissed that objection because the personnel of the Japanese corporate defendant were fluent in English. ${ }^{61}$ However, Professor Ohara points out that in a suit to enforce a U.S. judgment in Japan, a Japanese defendant's lack of understanding of English as an element of proper notice might be an issue. As he points out, in Julen $v$. Larson, ${ }^{62}$ a California appeals court declined to enforce a Swiss judgment based on process written in German, which the U.S. defendant did not understand.

The United States has acknowledged that the Convention is not clear about the necessity for translations and that further examination of the issue is desirable. Commenting that "there will be few instances where all of the documents" must be translated, a suggestion has been made that only a summary need be translated. ${ }^{63}$

As evidence of its cooperative attitude, the Advisory Committee on Civil Rules might well consider whether, in all cases of service abroad, a summary should be included in the language of the country where process is to be served. That is not as radical a proposal as it might at first appear; bilingual notices are already being used in this country in some instances. Rules of procedure in some states, including Pennsylvania, require that warnings to the defendant in

59. See also Wasden v. Yamaha Motor Co., 131 F.R.D. 206, 207 (M.D. Fla. 1990) (requiring plaintiff to send copy of complaint to defendant by registered mail); $c f$. Hammond v. Honda Motor Co., 128 F.R.D. 638 (D.S.C. 1989) (holding that service on Secretary of State would be valid since Article 10(a) allows service by mail). This matter is also discussed by the Committee on Fed. Courts of the N.Y. State Bar Ass'n, supra note 32, at 73-74.

60. Ohara, supra note 38 , at 16-17.

61. Shoie Kako v. Superior Court, 109 Cal. Rptr. 402, 413 (Cal. Ct. App. 1973).

62. 101 Cal. Rptr. 796, 798 (Cal. Ct. App. 1972).

63. Permanent Bureau, hague Conference on Private international law, 4 actes et DOCUMENTS DE LA QUATORZIÈmE SESSION, 6 AU 25 OCTOBRE 1980, 362-63 (1983). 
a civil suit be in Spanish as well as English. ${ }^{64}$ Requiring a plaintiff to provide a translated summary of judicial documents is hardly an unreasonable burden in transnational litigation. Such a provision would demonstrate a recognition that emphasis on international cooperation rather than on parochial concerns can do much to aid transnational litigation.

\section{VI \\ CONCLUSION}

The Hague Convention has greatly improved the means for serving process in transnational litigation. Nevertheless, even though the Convention established more relaxed rules, the signatories to the Convention have yet to universally accept the more flexible methods of service that are allowed in the United States.

The amendments to the Federal Rules of Civil Procedure represent a step forward for the creation of an easier and more efficient method of service of process in transnational litigation, but they are effective only to the extent that the country of receipt has not objected to the articles of the Convention that allow for mail service. For real progress, the signatories to the Convention must accept service by mail as appropriate in transnational litigation. That result may be some time in coming, however.

Closer to home, U.S. courts can aid in the establishment of more flexible procedures for service of process in transnational litigation by coming to a consensus on interpretations of the Hague Convention. As it now stands, courts are divided on whether service by mail is proper under the Convention. Because of some disparity in the language of Article 10(a), which only mentions the "freedom to send judicial documents" and does not explicitly refer to "service of process," some courts have concluded that service by mail is not proper. However, the decisions opposing that position, as well as the comments made by the drafters of the Convention, present a stronger case for the proposition that service by mail is acceptable under the Convention.

Even if uniformity among the courts should prevail, U.S. litigants still face the prospect of securing an unenforceable judgment in instances where a signatory has objected to service by mail. As transnational litigation becomes more common, as it surely will, one would hope that more countries will see the light and consent to more flexible methods of service.

64. See PA. R. CIV. P. 1018.1 (setting out a required notice to defendant of the nature of the suit and necessity to consult a lawyer). Subsection (d) provides "[a] court may by local rule require the notice to be repeated in one or more designated languages other than English." Pursuant to that provision, Rule 1018.1(B) of the local Philadelphia Civil Rules provides that "[ $t$ ]he notice required shall also be given in Spanish." Similarly, the model summons in App. XI-A to the New Jersey Court Rules, which corresponds with the New Jersey Rules of Civil Procedure Rule 4:4-2, states certain warnings in Spanish. 
